\title{
USING GENEALOGY TO IMPROVE SELECTION EFFICIENCY OF PEDIGREE METHOD
}

\author{
José Airton Rodrigues Nunes ${ }^{1}$; Alexsander Luís Moreto²; Magno Antonio Patto Ramalho* \\ ${ }^{1}$ UFPI/DPPA - C.P. 215 - 64049-550 - Teresina, PI - Brasil. \\ ${ }^{2}$ UFLA - Depto. de Biologia, C.P. 3037 - 37200-000 - Lavras, MG - Brasil. \\ *Corresponding author <magnoapr@ufla.br>
}

\begin{abstract}
In the pedigree method of conducting an autogamous population of segregating plants, the genealogy of the progenies is registered. Although labor-intensive, these data are rarely used. One possibility of exploiting this information is to improve selection efficiency using BLUP (Best Linear Unbiased Prediction). In this study BLUP with genealogy inclusion was compared to the mean in the progenies evaluation conducted by the pedigree method. Progenies of crosses of the common bean lines BRS MG Talismã and BRS Valente in $\mathrm{F}_{4: 6}$ and $\mathrm{F}_{4: 7}$ were used. The $256 \mathrm{~F}_{4: 6}$ progenies were sown in February 2005, in southeast of Brazil, in a $16 \times 16$ simple lattice design. The grain yield data were subjected to BLUP analysis with inclusion of genealogy. Based on this analysis and the mean, the 30 progenies with best and worst performance were selected. These $60 \mathrm{~F}_{4: 7}$ progenies were classified in relation to the origin, i.e., selected by BLUP, mean, or BLUP and mean and coincident results were obtained. In the selection for best performance, the efficiency of BLUP was $2.4 \%$ higher than the mean. In the selection for the opposite extreme, BLUP analysis was however not advantageous. The progenies $\times$ environments interaction indicates the need for an evaluation of the progenies in different environments before beginning selection.

Key words: BLUP, selection method, bean improvement, heritability, quantitative genetics

\section{EMPREGO DA GENEALOGIAPARA MELHORAR EFICIÊNCIA SELETIVANO MÉTODO PEDIGREE}

\begin{abstract}
RESUMO: No método do pedigree de condução de população segregante de plantas autógamas, é anotado a genealogia das progênies. Contudo, normalmente essa informação embora trabalhosa, não é utilizada. Uma das opções é usar esta informação para melhorar a eficiência da seleção empregando o BLUP (Best Linear Unbiased Prediction). Nesse trabalho, foi comparado BLUP com a inclusão de genealogia em relação à média na avaliação de progênies conduzidas pelo método genealógico. Para isto foram utilizadas progênies $\mathrm{F}_{4 \cdot 6}$ e $\mathrm{F}_{4 \cdot 7}$ do cruzamento entre as linhagens de feijão BRS MG Talismã e BRS Valente. As 256 progênies $\mathrm{F}_{4 \cdot 6}$ foram semeadas em fevereiro de 2005, no sudeste do Brasil, no delineamento látice simples $16 \times 16$. Os dados de produtividade de grãos foram submetidos à análise do BLUP com inclusão da genealogia. A partir dessa análise, e considerando a média, foram selecionadas as 30 progênies com melhor e pior desempenho. Essas 60 progênies $\mathrm{F}_{4: 7}$ foram novamente avaliadas e verificada a coincidência na classificação em função da origem, isto é, selecionadas pelo BLUP, média ou BLUP e média. Constatou-se que na seleção efetuada para melhor desempenho o BLUP apresentou eficiência 2,4\% acima da obtida com a média, contudo, na seleção efetuada no extremo oposto, não houve vantagem da análise com BLUP. A ocorrência de interação progenies $\times$ ambientes evidencia a necessidade de se realizar a avaliação das progênies em alguns ambientes antes de se proceder à seleção.

Palavras-chave: BLUP, métodos de seleção, melhoramento do feijoeiro, herdabilidade, genética quantitativa
\end{abstract}

\section{INTRODUCTION}

The success of improvement in the development of plants with higher grain yield, fruits and fiber is evident. However, the continuously increasing demand calls for further genetic progress in the future. Continuous success in selection programs depends on the use of all improvement strategies available.
In the case of autogamous plants, among the different methods of advancing segregating populations, the genealogy or pedigree method is particularly interesting. A peculiarity of this method is that the genealogy of the progenies in the selfing generations is registered. But, in spite of rather time-consuming for breeders, the compiled genealogy is practically not used at all (Ramalho et al., 2001). On this background, 
the mixed model analysis, as proposed by Henderson in 1959, is well-suited since this information on genetic progeny similarity is considered for selection purposes (Resende, 2002). The progenies are thus selected based on their genetic estimates that take not only the performance per se into account, but the performance of related progenies as well. These estimates represent the Best Linear Unbiased Prediction - BLUP (Henderson, 1975).

The advantageous effect of the inclusion of parentage information in plant improvement has been described elsewhere (Panter \& Allen, 1995; Bromley et al., 2000). In a simulation study with $\mathrm{F}_{4: 5}$ progenies conducted by the pedigree method, Nunes (2006) evidenced that the BLUP procedure, considering the parentage, proved advantageous over selection based on the phenotypic mean, especially in conditions of low heritability. This information was however not corroborated by experimental data.

This study aimed to compare the selection efficiency of BLUP including genealogy information to the phenotypic mean of common bean progenies, conducted by the pedigree method.

\section{MATERIAL AND METHODS}

The experiment was conducted in Lavras, state of Minas Gerais, Brazil (21ำ $14^{\prime} \mathrm{S}, 40^{\circ} 17^{\prime} \mathrm{W}, 918 \mathrm{~m}$ asl). Two cultivars were used as parents of the segregating common bean population: BRS MG Talismã, of indeterminate growth habit (type III), with cream-colored seeds with light brown stripes, resistant to Colletotrichum lindemuthianum (pathotypes 65, 67, 73, $75,81,83,89,95$, and 117), to the bean common mosaic virus (BCMV) and with intermediate resistance to angular leaf spot; and secondly BRS Valente, with indeterminate growth habit (type II), black grain, resistant to anthracnose (pathotypes 89, 95, 453, and 585) and BCMV, and intermediate resistant to angular leaf spot.

$F_{1}$ seeds were obtained through artificial crosses of the above described parents, performed in a greenhouse (Peternelli \& Borém, 1999). The $F_{1}$ and $\mathrm{F}_{2}$ plants were grown under field conditions. The following generations up to the $\mathrm{F}_{4: 5}$ progenies were conducted by the pedigree method as follows: $64 \mathrm{~F}_{2}$ plants were collected individually generating $64 \mathrm{~F}_{2: 3}$ progenies that were sown in rows in the following growing season. Two plants of each $\mathrm{F}_{2: 3}$ progeny were randomly collected, which originated the $128 \mathrm{~F}_{3: 4}$ progenies. In turn, these were sown again and two plants per row originated the $256 \mathrm{~F}_{4: 5}$ progenies.

The $\mathrm{F}_{4: 5}$ progenies were planted in a row and $256 \mathrm{~F}_{4: 6}$ progenies were bulk-harvested which were sown in February 2005 and evaluated in the dry sea- son. The experimental design was a $16 \times 16$ simple lattice. The experimental plots consisted of $2 \mathrm{~m}$ long rows, spaced $50 \mathrm{~cm}$ apart, with 15 seeds per meter. The other cultural treatments were the regionally applied for common bean. The evaluated trait was grain yield.

The data were analyzed in two ways: by the conventional approach with analysis of variance, using the following statistical model:

$y_{i j k}=\mu+r_{j}+b_{k(j)}+a_{i}+e_{i j k}$, where: $y_{i j k}$ : observation of the plot that received progeny $i$ in block $k$ within replication $j(i=1,2, \ldots, 256 ; j=1,2 ; k=1,2, \ldots, 16) ; \mu$ : constant associated to all observations; $r_{j}$ : fixed effect of replication $j ; b_{k(j)}$ : random effect of block $k$ within replication $j ; a_{i}$ : random effect of progeny $i ; e_{i j k}$ : random experimental error associated to observation $y_{i j k}$.

The second approach focused on the mixed model. For this purpose, the previous statistical model was re-expressed in the matrix form by:

$y=X \beta+Z_{1} b+Z_{2} a+e$, where: $\boldsymbol{y}$ : vector of phenotypic data of the plots, in the dimensions $512 \times 1 ; X$ : matrix of the model of the fixed effects $\boldsymbol{\beta}$, dimensions $512 \times 3 ; \boldsymbol{\beta}$ : vector of the fixed effects, $3 \times 1 ; Z_{l}$ : matrix of the model of the random effects of blocks within replications $\boldsymbol{b}, 512 \times 32 ; \boldsymbol{b}$ : vector of the random effects of blocks within replications, $32 \times 1$, with $\boldsymbol{b} \sim N\left(0, I \sigma_{b}^{2}\right) ; Z_{2}$ : matrix of the model of the random effects of progenies $\boldsymbol{a}, 512 \times 256$; $\boldsymbol{a}$ : vector of the random effects of the progenies, $256 \times 1$, with $\boldsymbol{a} \sim N(0, G)$, where $G$ is the matrix of genetic additive covariances between the random progeny effects; $\boldsymbol{e}$ : error vector, dimensions $512 \times 1$, with $\boldsymbol{e} \sim N(0, R)$, where $R=I \sigma_{e}^{2}$.

The genetic additive matrix of covariances between the random effects of progenies (matrix $G$ ) can be determined by the matrix of genetic additive parentage between the progenies multiplied by the component of variance associated to these random effects - $G=A \sigma_{a}^{2}$ (Mrode, 1996; Lynch \& Walsh, 1998). According to the described conduction of the segregating population, each $\mathrm{F}_{2}$ plant generated four related $\mathrm{F}_{4: 6}$ progenies, provided that the $\mathrm{F}_{2}$ generation is assumed in equilibrium. Based on this known genealogy of the $\mathrm{F}_{4: 6}$ progenies, the coefficients of additive parentage were thus determined, as well as elements of matrix $A$, which correspond to twice Malecot's coancestry coefficient of the progenies. For the $\mathrm{F}_{4: 6}$ progenies, matrix $A$ is therefore given by:

$A=I_{64} \otimes,\left[\begin{array}{cccc}1.875 & 1.50 & 1.00 & 1.00 \\ 1.50 & 1.875 & 1.00 & 1.00 \\ 1.00 & 1.00 & 1.875 & 1.50 \\ 1.00 & 1.00 & 1.50 & 1.875\end{array}\right]$

where: $\otimes$ symbolizes the Kronecker matrix product. 
The statistical analyses were performed using the Mixed procedure of the SAS 8.0 software package (Littlel et al., 1996; SAS, 1999). After the data analysis of the $\mathrm{F}_{4: 6}$ progenies, 60 progenies (30 with best and 30 with worst performance) were selected by the mean and by BLUP. These 60 progenies, as well as the $\mathrm{F}_{4: 7}$ generation and four controls (BRS MG Talismã, BRS Valente, VC-3 and OP-NS 331) were evaluated again in a field experiment in the wet season sown in November 2005, in an $8 \times 8$ triple lattice design. The plots had two rows of two meters, spaced $50 \mathrm{~cm}$ apart. The management was similar to the previous and grain yield data were obtained. The mentioned model was also used in the subsequent analysis of variance. Based on the joint analysis of the $F_{4: 6}$ and $\mathrm{F}_{4: 7}$ progenies, the components of the progenies ", generations interaction were partitioned, as shown by Cruz et al. (2004).

For the $\mathrm{F}_{4: 6}$ as well as the $\mathrm{F}_{4: 7}$ progenies the components of genetic variance were estimated based on the mean square expectations. The confidence intervals $(C I)$ associated to the estimates of the genetic variance components were estimated based on the following expression (Ramalho et al., 2005):

$C I=P\left[\frac{V \sigma_{p}^{2}}{\chi_{\alpha / 2}^{2}}<\sigma_{p}^{2}<\frac{V \sigma_{p}^{2}}{\chi_{1-\alpha / 2}^{2}}\right]=(1-\alpha) 100 \%$,

where: $\alpha: 0.05$ level of significance; $\hat{\sigma}_{p}^{2}$ : estimate of genetic variance in progenies; $V:$ number of degrees of freedom associated to component $\hat{\sigma}_{p}^{2}$, which was obtained according to Satterthwaite (1946); $\chi_{\alpha / 2}^{2}$ and $\chi_{1-\alpha / 2}^{2}$ : superior quantiles tabled in the $\chi^{2}$ (Chi-square) distribution for $V$ degrees of freedom.
Furthermore, the heritability $\left(\hat{h}^{2}\right)$ for selection in the progeny mean was estimated based on the mean square expectations of the analysis of variance (Vencovsky \& Barriga, 1992). The errors associated to the estimate were determined according to Knapp et al. (1985).

\section{RESULTS AND DISCUSSION}

Differences $(P \leq 0.01)$ were verified between the $\mathrm{F}_{4: 6}$ progenies regarding grain yield (Table 1). The significance of the effect of progenies was reinforced by the genetic and phenotypic parameter estimates of this generation (Table 2). The estimate of the genetic variance in $\mathrm{F}_{4: 6}$ progenies is different from zero, with a lower positive limit. The lower limit of $h^{2}$ is positive, which allowed the conclusion that it is also different from zero, with $95 \%$ probability. The $h^{2}$ estimate was higher than $47 \%$. The heritability can be considered as in the narrow sense, since dominance variance $\sigma_{D}^{2}$ is o f little relevance in autogamous crops (Van Oeveren \& Stam, 1992). In the particular case of common bean, contribution of $\sigma_{D}^{2}$ to the genetic variance in grain yield is low (Moreto et al., 2007). Moreover, only 31/256 of $\left(\sigma_{D}^{2}\right)$ present in $\mathrm{F}_{2}$ is exploited in $\mathrm{F}_{4: 5}$ progenies.

Different $h^{2}$ estimates for common bean grain yield have been proposed in the literature. In a data collection (including 22 estimates) the mean estimate of this parameter was $32 \%$ (Moreto et al., 2007). A comparison of $h^{2}$ estimates is not easy, owing to variations due to the progeny type and the experimental conditions. Still, the $h^{2}$ value obtained here $(47 \%)$ with $\mathrm{F}_{4: 6}$ progenies was higher than the estimated mean based on the revision (Table 2). These results evidence the possibility of success with selection in this segregating population, which was a basic condition for the conduction of this study.

Table 1 - Summary of the individual analyses of variance in the $F_{4: 6}$ and $F_{4: 7}$ generations and the joint analysis of both generations for grain yield ( $\mathrm{g} / \mathrm{plot}$ ), Lavras, MG.

\begin{tabular}{|c|c|c|c|}
\hline Generation & Source & d.f. & M.S. \\
\hline \multirow[t]{4}{*}{$\mathrm{F}_{4: 6}$} & Progenies $(\mathrm{P})$ & 255 & $24439 * *$ \\
\hline & Selected progenies (SP) & 59 & $68162 * *$ \\
\hline & Error & 255 & 12722 \\
\hline & V.C..(\%) & & \\
\hline \multirow[t]{3}{*}{$\mathrm{F}_{4: 7}$} & Progenies (SP) & 59 & $20346 *$ \\
\hline & Error & 105 & 12152 \\
\hline & V.C.(\%) & & \\
\hline \multirow[t]{5}{*}{ Joint } & Generation $(\mathrm{G})$ & 1 & 56722 \\
\hline & Progenies (SP) & 59 & $61472 *$ \\
\hline & $\mathrm{G} \times(\mathrm{SP})$ & 59 & $36843 * *$ \\
\hline & Error & 360 & 12437 \\
\hline & V.C. $(\%)$ & & \\
\hline
\end{tabular}


The BLUP method was applied together with the genealogy, in the hope of improving the selection efficiency as suggested elsewhere (Lynch \& Walsh, 1998; Resende, 2002). Considering the results of BLUP as well as the means, the 30 best and 30 worst-performing progenies were identified (Table 3). Remarkably, of this total, nine of the best progenies were selected by both procedures (mean and BLUP), only eleven by the BLUP and ten by the mean. Thus, 20 best-performing progenies were selected in the BLUP and 19 with the mean. In the negative sense the proportions were similar. In this way it was possible to evaluate the efficiency of the mean and of the BLUP in the selection process under similar conditions. Furthermore, in terms of mean grain yield the progenies selected by BLUP and those by the mean did not coincide particularly well, especially regarding the worstperforming progenies for both selection criteria (Table 3).

The analysis of joint variance of the common progenies presented significant differences between progenies (Table 1). Moreover, the effect of the progenies $\times$ generations interaction was significant $(P \leq$ $0.01)$. The estimate of the genetic correlation between the progeny means in both generations $\left(r_{g}=0.59\right)$ was not high, indicating that the progeny performance was not coincident in the two environments. Even in the

Table 2 - Estimates of genetic variance in progenies $\left(\sigma_{p}^{2}\right)$; residual variances $\left(\sigma_{e}^{2}\right)$; heritability in the progeny means $\left(h_{r}^{2}\right)$ for the trait grain yield ( $\mathrm{g}$ per plot) of the $\mathrm{F}_{4: 6}$ progenies conducted by the pedigree method.

\begin{tabular}{crrr}
\hline Parameters & Estimates & \multicolumn{1}{c}{ L.L. ${ }^{1 /}$} & \multicolumn{1}{c}{ U.L. } \\
\hline$\sigma_{p}^{2}$ & 5858.61 & 3249.71 & 13569.45 \\
$\sigma_{e}^{2}$ & 12722.19 & 10773.46 & 15255.07 \\
$h_{r}^{2}$ & $47.94 \%$ & 33.42 & 59.30 \\
\hline
\end{tabular}

${ }^{1 /}$ L.L : lower limit; U.L : upper limits

Table 3 - Number of progenies selected by the mean, BLUP, mean/BLUP and their respective lower (L.L.) and upper limits (U.L.) of grain yield in the $\mathrm{F}_{4: 6}$ generation.

\begin{tabular}{|c|c|c|c|c|}
\hline & Criteria & $\begin{array}{c}\mathrm{n}^{\circ} \text { of selected } \\
\text { progenies }\end{array}$ & L.L. & U.L. \\
\hline Positive & Mean & 10 & 308.01 & 442.71 \\
\hline \multirow[t]{2}{*}{ Selection } & BLUP & 11 & 264.81 & 442.71 \\
\hline & Mean/BLUP & 9 & 315.69 & 442.71 \\
\hline Negative & Mean & 11 & 62.44 & 148.31 \\
\hline \multirow[t]{2}{*}{ Selection } & BLUP & 11 & 126.87 & 183.87 \\
\hline & Mean/BLUP & 8 & 62.44 & 144.65 \\
\hline
\end{tabular}

case of the progenies performance coincided in the selection, their classification was different (Table 4). The occurrence of progenies $\times$ environments interaction in common bean is well-documented (Carneiro et al., 2002; Pereira, 2003; Aguiar et al., 2004).

The main focus of this study was to verify whether there is any difference between the BLUP method and the progeny means. Among the 30 superior and 30 inferior progenies selected in the $\mathrm{F}_{4: 6}$, 19 coincided in both groups in the following generation $\left(\mathrm{F}_{4: 7}\right)$. Of the progenies identified as superior in $\mathrm{F}_{4: 6}$, by the mean as much as by BLUP, $88.9 \%$ were also among the 30 best in $\mathrm{F}_{4: 7^{\circ}}$ On the other hand, the coincidence for those identified by the BLUP or by the mean only was lower. Considering the selection of the $20 \mathrm{~F}_{4: 6}$ progenies by the BLUP, 14 coincided $(70.0 \%)$. By the mean however, of the 19 progenies identified among the 30 best in $F_{4: 6}, 13$ coincided with good performance in $\mathrm{F}_{4: 7}(68.4 \%)$. Consequently, the BLUP presented an efficiency of only $2.4 \%$ over the mean. However, in the selection for the opposite extreme, the efficiency was the same (Table 5).

BLUP is particularly recommended when there is an imbalance and/or covariances between genotypes. In the case of the evaluations of progenies in autogamous plants the imbalance is hardly ever significant. In this situation the results of the BLUP are equivalent to the mean for non-related genotypes (Bernardo, 2002). However, since the genealogy of the progenies makes it possible to measure the parentage among the progenies in the pedigree method of conducting segregating populations, its use in the BLUP would be a possibility to increase the selection efficiency, justifying the collection of this information.

According to the simulation, the advantage in the selection accuracy of BLUP over the mean increases with the reduction of $h^{2}$ (Nunes, 2006). With a $h^{2}$ of $50 \%$, a similar value to that of the $\mathrm{F}_{4: 6}$ progenies obtained in the present study (Table 2) and with a selection intensity of $10 \%$, equivalent to the one used here, the selection efficiency of the BLUP compared to the mean would be 0.7 percentage points, that is, a slightly inferior value than observed here when selection was performed in the positive sense. In view of the heritabilities that were obtained in common bean improvement programs for the trait grain yield, the advantage of BLUP is probably not worth the effort of recording genealogy. A greater effort must be made in the moment of evaluating the progenies, which should be evaluated in a larger number of environments to reduce the effect of the progenies $\times$ environments interaction. 
Table 4 - Classification of the coincident progenies in the $\mathrm{F}_{4: 6}$ and $\mathrm{F}_{4: 7}$ generations and their origin in relation to the selection criterion used.

\begin{tabular}{|c|c|c|c|c|c|c|c|c|c|}
\hline \multicolumn{2}{|c|}{ Classification } & \multirow[b]{2}{*}{$\mathrm{M}^{2 /}$} & \multirow[b]{2}{*}{ BLUP } & \multirow[b]{2}{*}{ M/BLUP } & \multicolumn{2}{|c|}{ Classification } & \multirow[b]{2}{*}{ M } & \multirow[b]{2}{*}{ BLUP } & \multirow[b]{2}{*}{ M/BLUF } \\
\hline $\mathrm{F}_{4: 6}$ & $\mathrm{~F}_{4: 7}$ & & & & $\mathrm{~F}_{4: 6}$ & $\mathrm{~F}_{4: 7}$ & & & \\
\hline $27^{1 /}$ & 1 & - & $\mathrm{x}$ & - & 44 & 32 & $\mathrm{x}$ & - & - \\
\hline 14 & 2 & - & - & $\mathrm{x}$ & 36 & 33 & - & $\mathrm{x}$ & - \\
\hline 2 & 4 & - & - & $\mathrm{x}$ & 58 & 35 & - & - & $\mathrm{x}$ \\
\hline 28 & 6 & - & $\mathrm{x}$ & - & 47 & 37 & $\mathrm{x}$ & - & - \\
\hline 3 & 7 & - & - & $\mathrm{x}$ & 55 & 40 & - & - & $\mathrm{x}$ \\
\hline 1 & 8 & - & - & $\mathrm{x}$ & 48 & 41 & $\mathrm{x}$ & - & - \\
\hline 22 & 9 & - & $\mathrm{x}$ & - & 34 & 42 & - & $\mathrm{x}$ & - \\
\hline 8 & 10 & $\mathrm{x}$ & - & - & 40 & 45 & - & $\mathrm{x}$ & - \\
\hline 25 & 11 & - & $\mathrm{x}$ & - & 37 & 46 & - & $\mathrm{x}$ & - \\
\hline 16 & 12 & - & - & $\mathrm{x}$ & 54 & 47 & $\mathrm{x}$ & - & - \\
\hline 24 & 13 & - & $\mathrm{x}$ & - & 50 & 51 & $\mathrm{x}$ & - & - \\
\hline 13 & 14 & $\mathrm{x}$ & - & - & 46 & 52 & - & - & $\mathrm{x}$ \\
\hline 7 & 18 & - & - & $\mathrm{x}$ & 42 & 53 & $\mathrm{x}$ & - & - \\
\hline 20 & 19 & - & $\mathrm{x}$ & - & 39 & 54 & - & $\mathrm{x}$ & - \\
\hline 15 & 23 & $\mathrm{x}$ & - & - & 43 & 55 & $\mathrm{x}$ & - & - \\
\hline 12 & 24 & - & - & $x$ & 49 & 56 & - & - & $\mathrm{x}$ \\
\hline 18 & 28 & $\mathrm{x}$ & - & - & 38 & 58 & - & $\mathrm{x}$ & - \\
\hline 5 & 29 & - & - & $\mathrm{x}$ & 57 & 59 & - & - & $\mathrm{x}$ \\
\hline 11 & 30 & $\mathrm{x}$ & - & - & 32 & 60 & - & $\mathrm{x}$ & - \\
\hline
\end{tabular}

${ }^{1 /}$ Classification of the progenies selected in $\mathrm{F}_{4: 6}$ and evaluated in $\mathrm{F}_{4: 7 .}{ }^{2 /}$ Selection in mean.

Table 5 - Expected and observed number of progenies in the $\mathrm{F}_{4: 7}$ generation by the selection based on the mean, BLUP and mean/BLUP in the $\mathrm{F}_{4: 6}$ generation, and percentage of coincidence.

\begin{tabular}{|c|c|c|c|c|c|c|}
\hline & \multicolumn{6}{|c|}{$\mathrm{F}_{4: 7}$} \\
\hline & \multicolumn{2}{|c|}{30 upper } & \multicolumn{2}{|c|}{30 lower } & \multicolumn{2}{|c|}{ Coincidence $(\%)$} \\
\hline & expected & observed & expected & observed & 30 upper & 30 lower \\
\hline mean & 10 & 5 & 11 & 7 & 50.0 & 63.6 \\
\hline BLUP & 11 & 6 & 11 & 7 & 54.5 & 63.6 \\
\hline mean/BLUP & 9 & 8 & 8 & 5 & 88.9 & 62.5 \\
\hline Total & 30 & 19 & 30 & 19 & & \\
\hline
\end{tabular}

\section{ACKNOWLEDGEMENTS}

To the CNPq and CAPES for the scholarships.

\section{REFERENCES}

AGUIAR, M.S.; RAMALHO, M.A.P.; ABREU, A.F.B.T.; CARNEIRO, J.E. de S. Effect of the number of intermatings on genetic properties of a segregant common bean population. Crop Breeding and Applied Biotechnology, v.4, p.234240, 2004

BERNARDO, R. Breeding for quantitative traits in plants. Woodbury: Stemma Press 2002. 368p.

BROMLEY, C.M.; VAN VLECK, L.D.; JOHNSON, B.E.; SMITH, O.S. Estimation of genetic variance in corn from $\mathrm{F}_{1}$ performance with and without pedigree relationship among inbred lines. Crop Science, v.40, p.651-655, 2000.
CARNEIRO, J.E. de S.; RAMALHO, M.A.P.; ABREU, A. de F.B.; GONÇALVES, F.M.A. Breeding potential of single, double and multiple crosses in common bean. Crop Breeding and Applied Biotechnology, v.2, p.515-524, 2002.

CRUZ, C.D.; REGAZZI, A.J.; CARNEIRO, P.C.S. Modelos biométricos aplicados ao melhoramento genético. 3.ed. Viçosa: UFV, 2004. v.1, 480p.

HENDERSON, C.R.; KEMPTHORNE, O.; SEARLE, S.R.; VON KROSIGK, C.M. The estimation of environmental and genetic trends from records subject to culling. Biometrics, v.13, p.192$218,1959$.

HENDERSON, C.R. Best linear unbiased estimation and prediction under a selection model. Biometrics, v.31, p.23-447, 1975.

KNAPP, S.J.; STROUP, W.W.; ROSS, W.M. Exact confidence intervals for heritability on a progeny mean basis. Crop Science, v.25, p.192-194, 1985.

LITTLEL, R.C.; MILLEKEN, G.A.; STROUP, W.W.; WOLFINGER, R.D. SAS ${ }^{\oplus}$ System for mixed models. Cary: SAS Institute, 1996. 633p. 
LYNCH, M.; WALSH, B. Genetics and analysis of quantitative traits. Sunderland: Sinauer, 1998. 948p.

MORETO, A.L.; RAMALHO, M.A.P.; NUNES, J.A.R.; ABREU, A.F.B. Estimação dos componentes da variância fenotípica em feijoeiro utilizando o método genealógico. Ciência e Agrotecnologia. v.31, p.1035-1042, 2007.

MRODE, R.A. Linear models for the prediction of animal breeding values. Guildford: Biddles, 1996. 184p.

NUNES, J.A.R. Incorporação da informação de parentesco no método genealógico pelo enfoque de modelos mistos. Lavras: UFLA, 2006. 113p. (Tese - Doutorado).

PANTER, D.M.; ALLEN, F.L. Using best linear unbiased predictions to enhance breeding for yield in soybean: II selection of superior crosses from a limited number of yield trials. Crop Science, v.35, p.405-410, 1995.

PEREIRA, H. S. Seleção de linhagens de feijão tipo Carioca com pirâmide de alelos de resistência à antracnose e outros fenótipos favoráveis. Lavras: UFLA, 2003. 78p. (Dissertação - Mestrado).

PETERNELLI, L.A.; BORÉM, A. Hibridação em feijão. In: BORÉM, A. Hibridação artificial de plantas. Viçosa: UFV, 1999. p.269-294.

RAMALHO, M.A.P.; ABREU, A.B.F.; SANTOS, J.B Melhoramento de espécies autógamas. In: NASS, L.L.; VALOIS, A.C.C.; MELO, I.S.; INGLIS, M.C.V. (Org.). Recursos genéticos \& melhoramento de plantas. Rondonópolis: Fundação MT, 2001. v.1, p.201-230.
RAMALHO, M.A.P.; FERREIRA, D.F.; OLIVEIRA, A.C. Experimentação em genética e melhoramento de plantas. 2.ed. Lavras: UFLA, 2005. 326p.

RESENDE, M.D.V. Genética biométrica e estatística no melhoramento de plantas perenes. Brasília: Embrapa Informação Tecnológica, 2002. 975p.

SAS INSTITUTE. SAS/STAT ${ }^{\circledR}$ 8.0 User's Guide. Cary: SAS Institute, 1999. 373p.

SATTERTHWAITE, F.E. An approximate distribution of estimates of variance components. Biometrics, v.2, p.110-114, 1946.

VAN OEVEREN, A.J.; STAM, P. Comparative simulation studies on the effects of selection for quantitative traits in autogamous crop: early selection versus single seed descent. Heredity, v.69, p.342-351, 1992.

VENCOVSKY, R.; BARRIGA, P. Genética biométrica no fitomelhoramento. Ribeirão Preto: Sociedade Brasileira de Genética, 1992. 496p.

Received October 18, 2006

Accepted September 06, 2007 